\title{
CTP : phosphocholine cytidylyltransferase in rat lung: relationship between cytosolic and membrane forms
}

\author{
Douglas A. Feldman, Mary Ellen Rounsifer, Linda Charles and Paul A. Weinhold \\ V.A. Medical Center and Department of Biological Chemistry, University Michigan, Ann Arbor, MI (U.S.A.)
}

(Received 30 January 1990)

Key words: Phosphatidylcholine; Cytidyltransferase; Fetal lung maturation; (Rat)

The purpose of these studies was to determine the properties of the membrane-bound cytidylyltransferase in adult lung and to assess the relationship between the microsomal enzyme and the two forms of cytidylyltransferase in cytosol. Microsomes, isolated by glycerol density centrifugation, contained significantly less cytidylyltransferase than microsomes isolated by differential centrifugation $(11.6 \pm 3.2 \mathrm{vs} .30 \pm 11 \mathrm{nmol} / \mathrm{min}$ per $\mathrm{g}$ lung). The released activity was recovered as $\mathbf{H}$-form cytidylyltransferase. Cytidylyltransferase activity was not removed from microsomes by washing of the microsomal pellet with homogenizing buffer. Triton X 100 extracted all of the cytidylyltransferase from microsomes. The extracted activity was similar to H-form. Chlorpromazine dissociated microsomal enzyme to L-form. Chlorpromazine has been shown previously to dissociate $\mathrm{H}$-form to L-form. These results suggested that microsomal cytidylyltransferase existed in a form similar if not identical to cytosolic H-form. In vitro translocation experiments demonstrated that the L-form of cytidylyltransferase was the species which binds to microsomal membranes. Triton $X$ 100 extraction of microsomes from translocations experiments removed the bound enzyme activity. Glycerol density fractionation indicated that the activity in the Triton extract was H-form cytidylyltransferase. We concluded that the active lipoprotein form of cytidylyltransferase (H-form) is the membrane-associated form of cytidylyltransferase in adult lung; that it is formed after the L-form binds to microsomal membranes and that cytosolic H-form is released from the membrane.

\section{Introduction}

Cytidylyltransferase (CTP : cholinephosphate-cytidylyltransferase, EC 2.7.7.15) is an important regulatory enzyme in the biosynthesis of phosphatidylylcholine (for reviews, see Refs. 1-3). A variety of experimental observations have indicated that the regulation of cytidylyltransferase activity is complex and may involve a variety of mechanisms. For example, cytidylyltransferase activity has been reported to be stimulated by phospholipids [4-7], modulated by phosphorylation [8-11] and increased by translocation from an inactive cytoplasmic pool to endoplasmic reticulum where it is activated $[2,12,13]$. Although these properties may reflect separate regulatory processes, the idea that membrane-bound cytidylyltransferase is the active form of the enzyme has become central in most regulating mechanisms. The strongest support for this idea comes from the observations that an increase in cytidyl-

Correspondence: P.A. Weinhold, V.A. Medical Center, Medical Research 151, 2215 Fuller Road, Ann Arbor, MI 48105, U.S.A. yltransferase activity in membrane fractions correlates with an increase in the conversion of radiolabeled choline phosphate to phosphatidylcholine in cell culture experiments $[12,14-20]$. However, it is not clear in all cases that the increase in membrane activity is due to translocation of cytoplasmic enzyme [19-22]. Furthermore, increased phosphatidylcholine synthesis in fetal lung preparations has been correlated with an increase in cytoplasmic cytidylyltransferase activity with no apparent redistribution of activity to membranes [7,23]. Thus, the relationships between cytoplasmic cytidylyltransferase activity and membrane-bound activity in the overall regulation of the enzyme activity requires further clarification.

The regulation and coordination of phosphatidylcholine synthesis in lung is particularly interesting, since relatively large amounts of phosphatidylcholine must be synthesized for the continued production of pulmonary surfactant in addition to the requirement for phosphatidylcholine turnover as part of membrane structure and function. Earlier studies on cytidylyltransferase in lung revealed that cytosolic preparations contain two forms of cytidylyltransferase, possessing different apparent 
molecular weights [24]. The higher $M_{\mathrm{r}}$ form (H-form) is particularly abundant in adult lung [4]. Further characterizations of these forms revealed that the lower $M_{\mathrm{r}}$ form (L-form) has an $M_{\mathrm{r}}$ of 98000 and appears to be a homodimer of the $42000 M_{\mathrm{r}}$ subunit [25]. This form is essentially inactive in the absence of lipid. The H-form has an apparent $M_{\mathrm{r}}$ of about 284000 and is active without the addition of phospholipid to the assay. Since the $\mathrm{H}$-form could be dissociated into L-form and could be regenerated from L-form by the addition of phospholipids which activated the L-form activity, we suggested that the H-form is the active lipoprotein form of cytidylyltransferase [25]. Moreover, the recent report that two continuous cell lines (Hep G2 and A549) and isolated alveolar type II cells contained appreciable amounts of II-form [25] suggests that the II-form is a physiologically relevant form of cytidylyltransferase.

The purpose of the present investigation was to determine the molecular properties of membrane bound cytidylyltransferase and to examine the relationship between the cytosolic and membrane forms. The results demonstrate that the membrane bound form in lung is similar, if not identical, to the H-form in cytosol. Results from in vitro translocation experiments indicated that redistribution of cytosolic cytidylyltransferase depended upon the dissociation of $\mathbf{H}$-form to $\mathbf{L}$-form which in turn binds to membranes. These results suggest that the active lipoprotein form (H-form) may be formed at the membrane after the L-form has bound to the membrane.

\section{Materials and Methods}

Preparation of postmitochondrial supernatants and microsomes

Male adult rats (200-225 g, CrliCDBR, VAF/Plus, Charles River) were anesthetized. The lung or liver was perfused free from blood with isotonic saline at room temperature. The tissue was removed and homogenized in four volumes of $50 \mathrm{mM}$ imidazole, $0.15 \mathrm{M} \mathrm{KCl}, 2$ mM EDTA (pH 7.4) (homogenizing buffer). Connective tissue was removed by centrifugation at $1000 \times g$ for 10 min. The supernatant was centrifuged at $20000 \times g$ for $20 \mathrm{~min}$. The resulting supernatant was designated postmitochondrial supernatant. Microsomes were isolated from the $20000 \times g$ supernatant by centrifugation at $100000 \times g$ for $60 \mathrm{~min}$. The surface of the microsomal pellet was rinsed with cold homogenizing buffer. The pellet was suspended in homogenizing buffer (a volume equal to the original homogenate volume). A uniform suspension was made by homogenization in a glassTeflon homogenizer at low speed (motor driven). All steps were carried out at $4^{\circ} \mathrm{C}$.

Fetal lung was obtained from pregnant rats (20 days gestation). The mother was killed by decapitation and the fetuses removed. The lung was dissected and rinsed in cold saline. The tissue was processed as described above.

\section{Glycerol density centrifugation}

Glycerol density gradients $(7.2 \%$ to $36 \%, v / v)$ were prepared as previously described [25]. Samples $(1.0 \mathrm{ml})$ were applied to the top and the gradients were centrifuged at $347000 \times g(40000 \mathrm{rpm})$ in an SW41 rotor for $14 \mathrm{~h}$. Fractions were collected from the bottom of the tube. In all experiments, a trace amount of $\left[{ }^{3} \mathrm{H}\right]$ glycerol was added to the stock glycerol mixture used to prepare the $36 \%$ and $7.2 \%$ dilutions. The amount of ${ }^{3} \mathrm{H}$ in the gradient fraction was used to calculate the density. The microsomal pellet at the bottom of the gradient was suspended in homogenizing buffer by repeated extrusion through a 26 gauge needle.

\section{Extraction of microsomes with Triton X 100 or chlor- promazine}

Microsomes were suspended in homogenizing buffer $(1.1 \mathrm{mg} / \mathrm{ml} \mathrm{microsomal} \mathrm{protein).} \mathrm{Triton} \mathrm{X} 100(10 \%$ stock) was added to the microsome suspension to give a final concentration of $0.075 \%$. The mixture was stored at $4^{\circ} \mathrm{C}$ overnight. The Triton $\mathrm{X} 100$ extract was collected by centrifugation of the mixture at $100000 \times \mathrm{g}$ for $60 \mathrm{~min}$. Chlorpromazine was added from a $2 \mathrm{mM}$ stock solution to give a final concentration of $0.5 \mathrm{mM}$. After overnight storage at $4^{\circ} \mathrm{C}$, the extract was recovered by centrifugation $(100000 \mathrm{~g}$ for $60 \mathrm{~min}$ ).

\section{In vitro translocation}

Postmitochondrial supernatants $(20000 \mathrm{~g}$ for $20 \mathrm{~min}$ supernatant) were prepared and stored on ice. Aliquots (1.2-ml) were taken immediately for experiments. Oleic acid was added when appropriate from a $2.5 \mathrm{mM}$ stock. The stock oleic acid was prepared by sonication in homogenizing buffer. For incubation experiments, 1.2 $\mathrm{ml}$ of postmitochondrial supernatants was incubated in a $37^{\circ} \mathrm{C}$ water bath with constant agitation for the first $5 \mathrm{~min}$ and then mixed occasionally. Incubations were termination after $15 \mathrm{~min}$ by rapid cooling in ice water. Samples of $1.0 \mathrm{ml}$ were separated by glycerol density centrifugation.

\section{Enzyme assays}

Cytidylyltransferase activity was determined as previously described $[13,25]$. Cytidylyltransferase activity in microsomes was not proportional to the amount of microsomes in the assay above $8-10 \mu \mathrm{g}$ in a $100 \mu \mathrm{l}$ assay. Therefore, microsomal activity was determined using 5-8 $\mu \mathrm{g}$ microsomal protein per assay with a 30 min reaction time.

Choline phosphotransferase (CDP-choline: 1,2-diacylglycerol cholinephosphotransferase, EC 2.7.8.2) activity was measured using a 1,2-dioleoylglycerol-phos- 
phatidylglycerol-Tween 20 emulsion as described previously [26].

\section{Polyacrylamide electrophoresis and immunoblot analysis}

Polyacrylamide electrophoresis in the presence of sodium dodecyl sulfate (SDS) was performed using the buffer system of Laemmli [27] as described previously [28]. Cytosol samples were prepared by mixing an aliquot of cytosol with an equal volume of double strength sample buffer containing $2 \%$ SDS. Microsomes were extracted with $0.1 \%$ Triton $\mathrm{X} 100$. The Triton $\mathrm{X}$ 100 extract was the mixed with an equal volume of double strength sample buffer. Samples were boiled for $5 \mathrm{~min}$ in the presence of $5.0 \% \beta$-mercaptoethanol. Transblotting and immunodetection with cytidylyltransferase antibody was performed as previously described [25] except that ${ }^{125}$ I-labelled goat anti-rabbit IgG was used as the second antibody. Blots were developed by audioradiography using X-OMAT (Kodak) film.

\section{Materials and analytical methods}

All radioisotopes were purchased from New England Nuclear. Biochemicals were from Sigma. Protein was determined by the bicinchoninic acid (BCA) method [29] with reagents supplied by Pierce (Rockford, IL). Bovine serum albumin was used as the standard.

\section{Results}

\section{Microsomal forms of cytidylyltransferase}

Cytidylyltransferase associated with lung microsomes appeared to exist in a form similar, if not identical, to the $\mathrm{H}$-form aggregate in lung cytosol. Data supporting this conclusion is shown in Fig. 1 and Table I. Fig. 1 shows the results from an experiment designed to compare the distribution of cytidylyltransferase species in postmitochondrial supernatants $(20000 \times \mathrm{g}$ for $20 \mathrm{~min}$

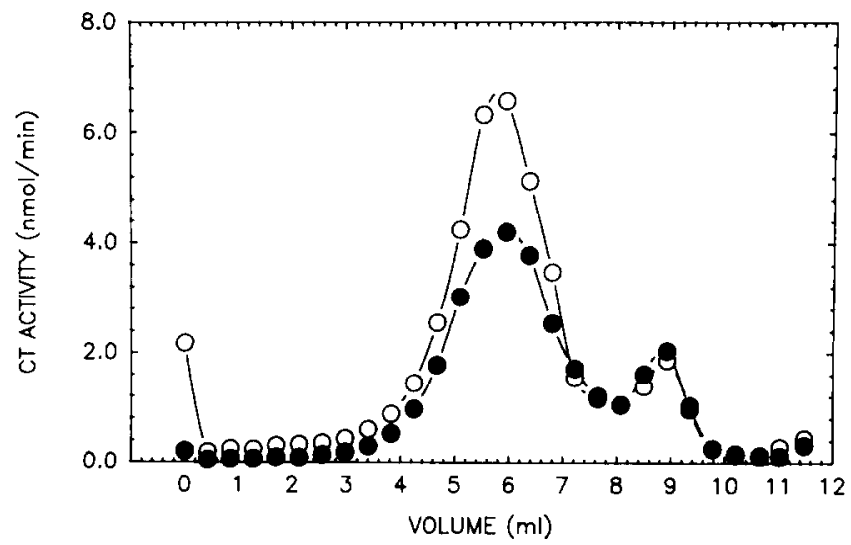

Fig. 1. Distribution of cytidylyltransferase activity in $20000 \times \mathrm{g}$ for 20 min supernatant (PMS) and in $100000 \times g$ for 60 min supernatant (cytosol). A $1.0 \mathrm{ml}$ sample of PMS (O), or cytosol ( $\bullet$ ), was separated directly on glycerol gradients. The bottom of the gradient is designated as 0 volume on the $x$ axis.
TABLE I

Comparison between differential centrifugation and glycerol gradient centrifugation method for the determination of the distribution of cytidylyltransferase

A $20000 \times g$ for $20 \mathrm{~min}$ supernatant (PMS) was prepared from lung. Microsomes and cytosol were isolated from $1.0 \mathrm{ml}$ of the PMS by centrifugation at $100000 \times g$ for $60 \mathrm{~min}$. The resulting cytosol was analyzed further by glycerol density centrifugation to determine the amounts of $\mathrm{H}$ and $\mathrm{L}$-form. This method was designated sedimented. A second $1.0 \mathrm{ml}$ of PMS was analyzed directly by glycerol density centrifugation and the distribution of cytidylyltransferase in microsomes, $\mathrm{H}$-form and L-form was determined. This method was designated Gradient.

\begin{tabular}{llll}
\hline $\begin{array}{l}\text { Cytidylyltrans- } \\
\text { ferase forms }\end{array}$ & \multicolumn{2}{l}{$\begin{array}{l}\text { CT activity } \\
\text { (nmol/min per }\end{array}$} & ml PMS) \\
\cline { 2 - 4 } & sedimented & gradient & difference \\
\hline H-form & 23.6 & 33.4 & +9.8 \\
L-form & 5.9 & 5.6 & - \\
Microsomes & 11.0 & 2.2 & -8.8 \\
Total recovered & 40.5 & 41.2 & - \\
\hline
\end{tabular}

supernatant) with the distribution in cytosol isolated by differential centrifugation at $100000 \times g$ for $60 \mathrm{~min}$. In this experiment, $1.0-\mathrm{ml}$ of postmitochondrial supernatant and a $1.0-\mathrm{ml}$ aliquot of cytosol, prepared from the same postmitochondrial supernatant, were fractionated by glycerol density centrifugation. A comparison of the profiles in Fig. 1 indicated that more $\mathrm{H}$-form cytidylyltransferase activity was recovered from the postmitochondrial supernatant sample than from the cytosol sample (after the microsomes had been removed by high speed centrifugation). A quantitative comparison of the relative distribution is shown in Table $\mathbf{I}$. The higher amount of activity in $\mathrm{H}$-form cytidylyltransferase coincided with a lower amount of activity in pelleted microsomes. Lung microsomes isolated from postmitochondrial supernatants by glycerol density centrifugation contained $11.6 \pm 3.2(n=9) \mathrm{nmol} / \mathrm{min}$ per g lung. This activity was about $40 \%$ of the activity recovered in microsomes isolated by sedimentation at $100000 \times g$ for $60 \mathrm{~min}(30 \pm 11 \mathrm{nmol} / \mathrm{min}$ per g lung, $n=10)$ and was comparable to the activity in liver microsomes $(7.7 \pm 0.8 \mathrm{nmol} / \mathrm{min}$ per $\mathrm{g}$ liver $n-4)$ isolated by sedimentation. Thus, centrifugation of microsomes through a glycerol density gradient removed cytidylyltransferase activity from the microsomes. The removed activity sedimented as $\mathrm{H}$-form. However, enzyme activity was not removed from microsomes by additional washing of microsomes that were prepared by sedimentation at $100000 \times g$ for $60 \mathrm{~min}$. In three separate experiments, microsomes were prepared at $100000 \times g$ for $60 \mathrm{~min}$, resuspended in homogenizing buffer and isolated again at $100000 \times \mathrm{g}$ for $60 \mathrm{~min}$. The original microsomes contained $6.1 \pm 0.2 \mathrm{nmol} / \mathrm{min}$ per $\mathrm{mg}$ protein. Microsomes after a single wash contained $5.7 \pm 0.2 \mathrm{nmol} / \mathrm{min}$ per mg protein. 


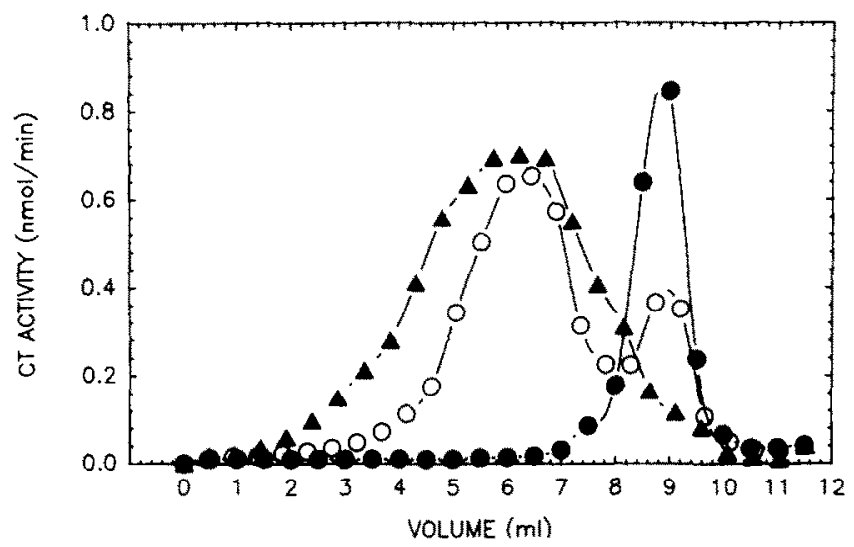

Fig. 2. Comparison of cytidylyltransferase forms. Triton $X 100$ extracts of microsomes, chlorpromazine extracts of microsomes and $100000 \times g$ for $60 \mathrm{~min}$ supernatants (cytosol) were fractionated on glycerol density gradients. Microsomes were extracted with either $0.075 \%$ Triton X 100 or $0.5 \mathrm{mM}$ chlorpromazine. The extracts were separated on glycerol gradients along with a sample of the lung cytosol. 4, Triton X 100 extract (7.5 units applied, 5.4 units recovered); - chlorpromazine extract ( 3.9 units applied, 2.3 units recovered); cytosol. The bottom of the gradient is designated as 0 volume.

Additional evidence supporting the contention that microsomes contained an aggregate form of cytidylyltransferase similar to $\mathbf{H}$-form is presented in Fig. 2. Triton X 100 was added to a microsomal suspension containing $59.0 \mathrm{nmol} / \mathrm{min}$ cytidylyltransferase activity and $17.1 \mathrm{mg}$ protein. The microsome - Triton mixture was centrifuged at $100000 \times \mathrm{g}$ for $60 \mathrm{~min}$. The supernatant contained $58.9 \mathrm{nmol} / \mathrm{min}$ cytidylyltransferase activity and $0.6 \mathrm{mg}$ protein. Thus, Triton X $100 \mathrm{ex}-$ tracted all of the cytidylyltransferase activity but only a small amount of the total protein. This extraction method did not remove cholinephosphotransferase activity (data not shown). The cytidylyltransferase activity in the Triton extract was in an aggregate form similar to the $\mathrm{H}$-form in cytosol, Fig. 2 . The enzyme activity peak from the Triton extract was broader than that from cytosol. The Triton extract may contain a more heterogeneous population of aggregates, perhaps due to the presence of lipids extracted by the Triton, which associated with the enzyme complex to give larger aggregates. The presence of lipids from microsomes may also explain the difference in the effects of Triton X 100 on cytosolic $\mathrm{H}$-form and microsomes. Prevously we found that treatment of cytosol with Triton X 100 dissociated the H-form to L-form [25]. However, as demonstrated here, Triton X 100 extraction of microsomes produced an $\mathrm{H}$-form type aggregate and did not dissociate this to the $\mathrm{L}$-form. In some experiments, a trace of ${ }^{14} \mathrm{C}$-Triton $X 100$ was included in the extraction mixture. Most of the Triton $(88 \%)$ remained at the top of the gradient. The aggregate band contained about $0.06 \mathrm{mg}$ of Triton (3\% of the total Triton X 100).

Chlorpromazine has been shown to dissociate the $\mathrm{H}$-form in cytosol to L-form [25]. Treatment of micro- somes with $0.5 \mathrm{mM}$ chlorpromazine solubilized $88 \%$ of the microsomal cytidylyltransferase activity. The solubilized activity was L-form cytidylyltransferase, Fig. 2. Thus, the microsomal enzyme aggregate and cytosolic $\mathrm{H}$-form are both dissociated to L-form by chlorpromazine.

Relationship between cytosolic and microsomal forms of cytidylyltransferase

The studies on microsomal cytidylyltransferase suggested that cytidylyltransferase activity associated with microsomal membranes was the $\mathrm{H}$-form previously found in lung cytosol. What then is the relationship between the two forms of cytidylyltransferase in cytosol (H-form and L-form) and the membrane-associated cytidylyltransferase? We reported previously that cytidylyltransferase activity could be translocated from cytosol to microsomes by the addition of oleic acid to postmitochondrial supernatants [13]. We used this in vitro system to examine the relationship between cytosolic and microsomal activity. Fractionation of postmitochondrial supernatants by glycerol density centrifugation enabled the simultaneous assessment of microsomal activity and the activity in the two cytosolic forms.

Incubation of postmitochondrial supernatants at $37^{\circ} \mathrm{C}$ for $15 \mathrm{~min}$ produced an increase in microsomal activity, an increase in L-form and a total disappearance of $\mathrm{H}$-form, Fig. 3. The addition of oleic acid after incubation at $37^{\circ} \mathrm{C}$ produced an additional increase in microsomal activity and a further decrease in L-form. The addition of oleic acid to postmitochondrial supernatants maintained at $4^{\circ} \mathrm{C}$ caused only a small increase in microsomal activity. There was no decrease in $\mathrm{H}$-form. In fact there was a small increase in $\mathrm{H}$-form activity. The decrease in L-form activity equalled the sum of the increased activity in $\mathrm{H}$-form and microsomes $(2.8 \mathrm{nmol} / \mathrm{min}$ decrease, 1.2 and $2.0 \mathrm{nmol} / \mathrm{min}$ increase in $\mathrm{H}$-form and microsomes). Overall, incubation at $37^{\circ} \mathrm{C}$ produced the greatest increase in microsomal cytidylyltransferase. The amount of binding induced by oleic acid was similar at $4^{\circ} \mathrm{C}$ and after incubation at $37^{\circ} \mathrm{C}$.

The increased microsomal cytidylyltransferase and the decreased cytosolic activity was due to binding of enzyme molecules. Fig. 4 contains Western Blots from two types of translocation experiments. In one type, postmitochondrial supernatants were incubated at $37^{\circ} \mathrm{C}$ followed by the addition of oleic acid. These were fractionated by glycerol density centrifugation along with control postmitochondrial supernatant which were kept at $4^{\circ} \mathrm{C}$. An increase in immunologically detected cytidylyltransferase was found in microsomes from the $37^{\circ} \mathrm{C}$ incubated samples. The second type of experiment involved sedimentation of the microsomes from postmitochondrial supernatant by centrifugation at 


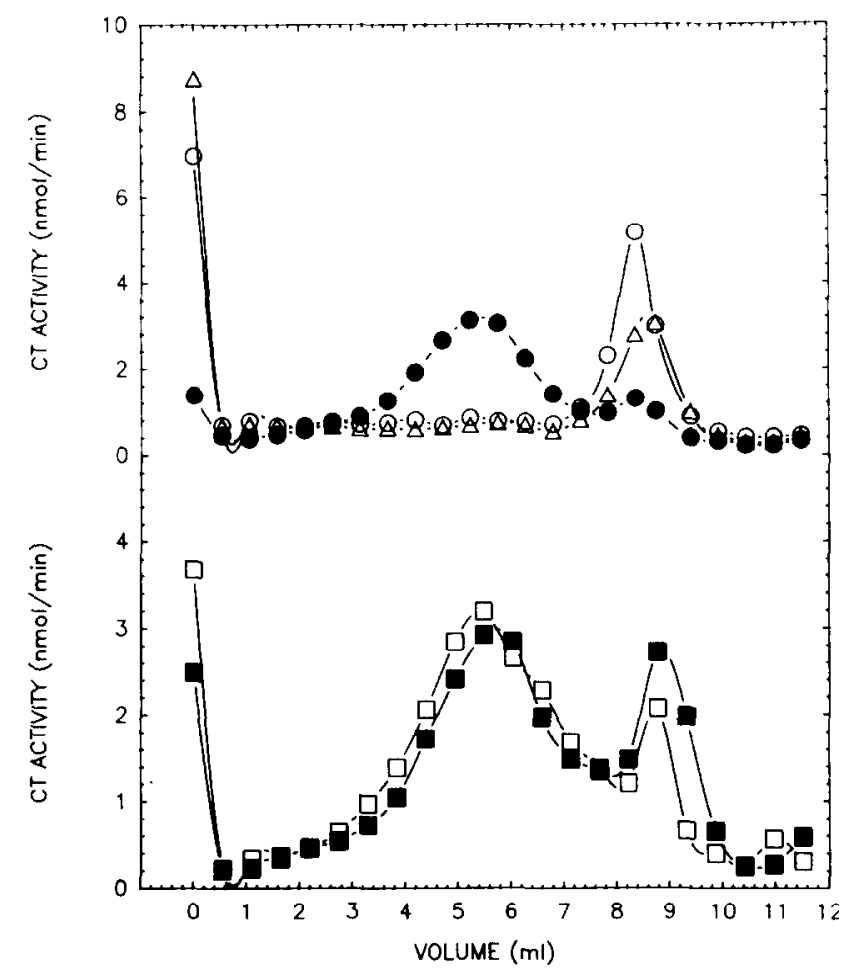

Fig. 3. The effect of incubation at $37^{\circ} \mathrm{C}$ and oleic acid on the distribution of cytidylyltransferase in $20000 \times \mathrm{g}$ for $20 \mathrm{~min}$ supernatants (PMS). Top: $\bullet$, PMS kept at $4^{\circ} \mathrm{C} ; \circ$, PMS incubated at $37^{\circ} \mathrm{C}$ for $15 \mathrm{~min} ; \Delta$, PMS incubated at $37^{\circ} \mathrm{C}$ for $15 \mathrm{~min}$ followed by the addition of oleic acid ( $250 \mu \mathrm{M}$ final concentration). The oleic acid-PMS mixture was incubated an additional $15 \mathrm{~min}$ at $4^{\circ} \mathrm{C}$; Bottom: n, PMS kept at $4^{\circ} \mathrm{C}$; 口, PMS after the addition of oleic acid $(250 \mu \mathrm{M})$ and incubation for $15 \mathrm{~min}$ at $4^{\circ} \mathrm{C}$. The top and bottom graphs used separate preparations of PMS.

$100000 \times g$ for $60 \mathrm{~min}$. There was an increase in immunologically detected cytidylyltransferase in microsomes and a decrease in cytosolic enzyme.

We reported previously that incubation of lung cytosol at $37^{\circ} \mathrm{C}$ caused dissociation of the $\mathrm{H}$-form to L-form [18]. In light of these results, it seems reasonable to conclude that incubation of postmitochondrial supernatants at $37^{\circ} \mathrm{C}$ would also dissociate the $\mathrm{H}$-form to L-form. The fact that incubation of postmitochondrial supernatants at $37^{\circ} \mathrm{C}$ promoted the binding of cytidylyltransferase to microsomal membranes suggested that it was the L-form of cytidylyltransferase which bound to microsomal membranes. However, this is circumstantial evidence. More direct evidence was obtained through the use of bovine serum albumin to reverse enzyme binding. Albumin was added to postmitochondrial supernatants after incubation at $37^{\circ} \mathrm{C}$ in the presence or absence of oleic acid. Fractionation of the albumin treated postmitochondrial supernatants by glycerol gradient centrifugation revealed that cytidylyltransferase was not bound to microsomes, but was recovered completely as the L-form, Fig. 5. No $\mathrm{H}$-form was detected. These results indicated that the L-form was the species which binds to membranes. Without albumin, the microsomes would contain newly bound enzyme. The glycerol gradient profiles of postmitochondrial supernatant treated with albumin at $4^{\circ} \mathrm{C}$ were the same as those from postmitochondrial supernatants not treated with albumin (data not shown). Thus, albumin did not cause dissociation of $\mathrm{H}$-form into $\mathrm{L}$-form or dissociation of microsomal activity. It appears that albumin dissociated only the newly bound cytidylyltransferase. These results also suggested that the binding induced by incubation at $37^{\circ} \mathrm{C}$ may involve fatty acids, since albumin released the bound enzyme. However, some caution should be used in this interpretation since albumin can bind other lipids in addition to fatty acids $[30,31]$.

Triton X 100 was used to release translocated cytidylyltransferase from microsomes. Postmitochondrial supernatants were incubated at $37^{\circ} \mathrm{C}$ for 15 min. Microsomes were isolated by glycerol density centrifugation and then extracted with Triton X 100. Triton

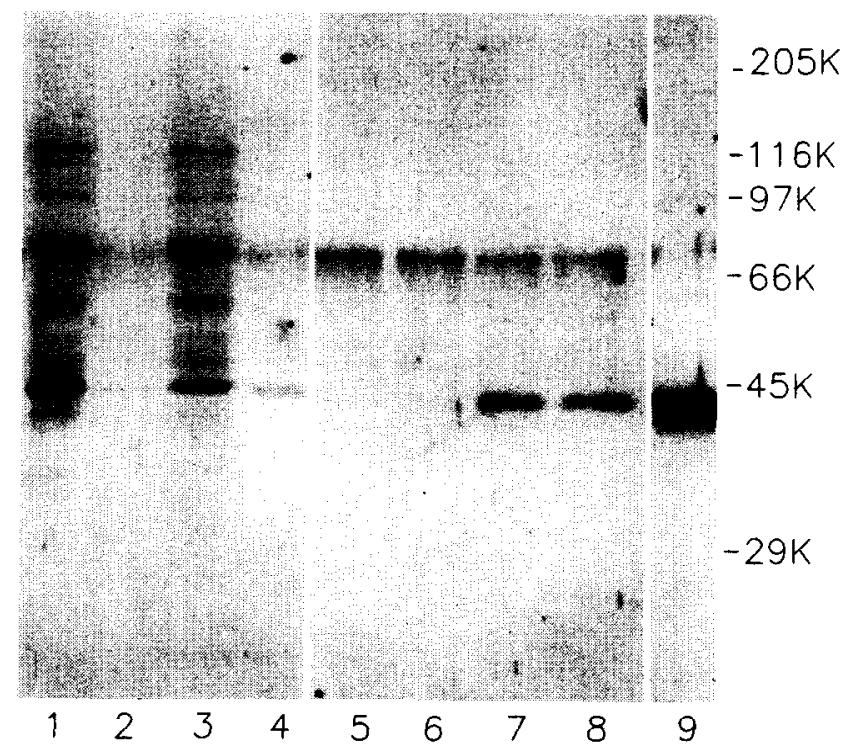

Fig. 4. Western Blot analysis of cytidylyltransferase translocation in adult lung. Postmitochondrial supernatant was prepared from adult lung. Four $1.5-\mathrm{ml}$ aliquots were removed. Two were incubated at $37^{\circ} \mathrm{C}$ for $15 \mathrm{~min}$ with $250 \mu \mathrm{M}$ oleic acid. The other two were kept at $4^{\circ} \mathrm{C}$ (control). Microsomes and cytosol were prepared from an incubated sample and from a control sample by centrifugation at $100000 \times \mathrm{g}$ for $60 \mathrm{~min}$. Microsomes were extracted with $0.1 \%$ Triton $\mathrm{X} 100$. A $25 \mu 1$ sample from cytosol and Triton extract was separated hy SDS polyacrylamide electrophoresis. Microsomes were also prepared from incubated and control postmitochondrial supernatants by glycerol density centrifugation. A 50- $\mu 1$ aliquot of the Triton extract was separated by electrophoresis. Lanes 1-4: microsomes and cytosol from $100000 \times g$ sedimentation. Lane 1, control cytosol: Lane 2, control microsomes; Lane 3, oleic acid cytosol; Lane 4, oleic acid microsomes. Lanes 5-8, microsomes isolated by glycerol gradients. Lane 5 and 6, control; lanes 7 and 8, oleic acid. Lane 9, purified cytidylyltransferase $(2 \mathrm{nmol} / \mathrm{min})$. The relative positions of molecular weight standards are shown at the right. The standards were Sigma MW-SDS 200 containing, rabbit myosin (205000), $\beta$-galactosidase $(116000)$, phosphorylase b $(97000)$, bovine serum albumin $(66000)$, ovalbumin (45000) and carbonic anhydrase (29000). 
X 100 extracted $81 \%$ of the microsomal cytidylyltransferase activity. Fractionation of the Triton extract showed that cytidylyltransferase activity was present as an aggregate similar to the $\mathrm{H}$-form, found in cytosol, Fig. 6 and in Triton extracts from $4^{\circ} \mathrm{C}$ microsomes, (see Fig. 2).

Cytidylyltransferase in liver and fetal lung cytosol was found totally in the L-form with no detectable $\mathrm{H}$-form $[24,25]$. Thus, in vitro translocation experiments with postmitochondrial supernatants from liver and fetal lung would involve only the L-form. The results from experiments with adult liver and fetal lung are presented in Figs. 7A and B, respectively. In contrast to adult lung, incubation at $37^{\circ} \mathrm{C}$ of adult liver or fetal lung postmitochondrial supernatant did not cause translocation of cytidylyltransferase. However, translocation was produced by the addition of oleic acid to postmitochondrial supernatants at $4^{\circ} \mathrm{C}$. The binding was doubled by incubation at $37^{\circ} \mathrm{C}$ in the presence of oleic acid. Therefore, although oleic acid promoted binding at $4^{\circ} \mathrm{C}$, the binding induced by oleic acid was significantly cnhanced by incubation at $37^{\circ} \mathrm{C}$. These results demonstrated directly that $\mathrm{L}$-form binds to membranes and that the binding requires oleic acid. Furthermore, even though incubation at $37^{\circ} \mathrm{C}$ did not produce bind-

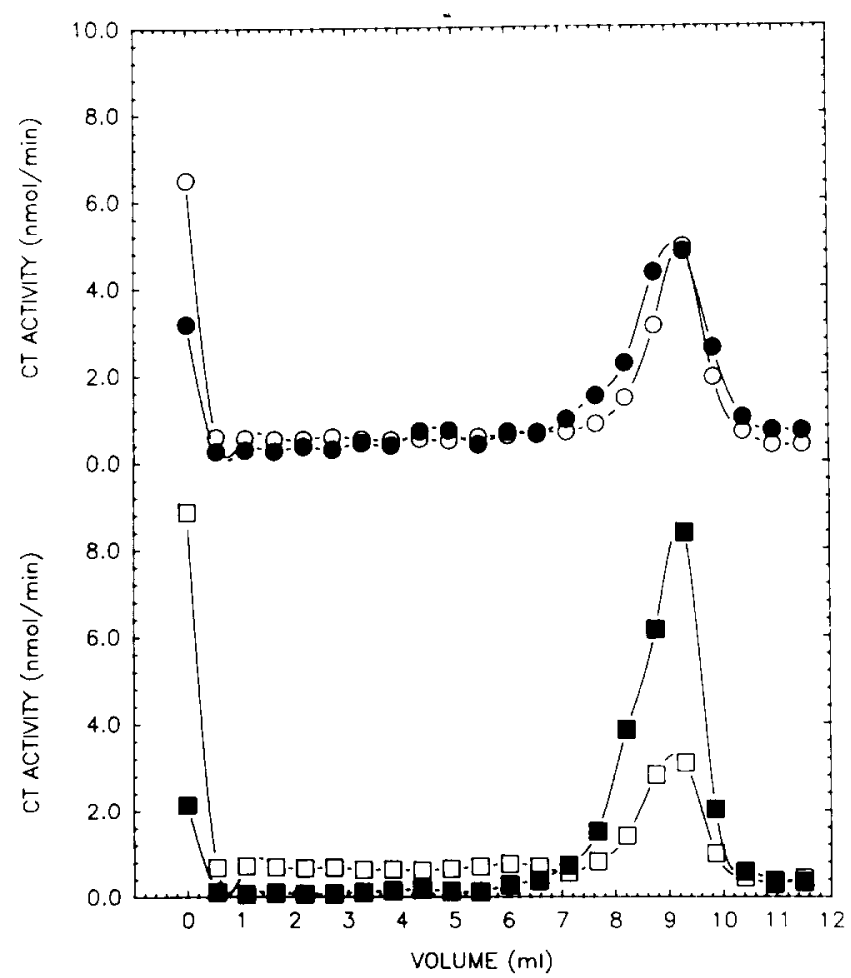

Fig. 5. The effect of bovine serum albumin (BSA) on the distribution of cytidylyltransferase in $20000 \times \mathrm{g}$ for $20 \mathrm{~min}$ supernatant. O, PMS incubated at $37^{\circ} \mathrm{C}$ for $15 \mathrm{~min}$;, , PMS incubated at $37^{\circ} \mathrm{C}$ for $15 \mathrm{~min}$, then BSA added to give a final concentration of $0.5 \%$; $\square$, PMS incubated at $37^{\circ} \mathrm{C}$ for $15 \mathrm{~min}$ with $250 \mu \mathrm{M}$ oleic. PMS incubated at $37^{\circ} \mathrm{C}$ for $15 \mathrm{~min}$ with $250 \mu \mathrm{M}$ oleic, then BSA added to give a final concentration of $0.5 \%$.

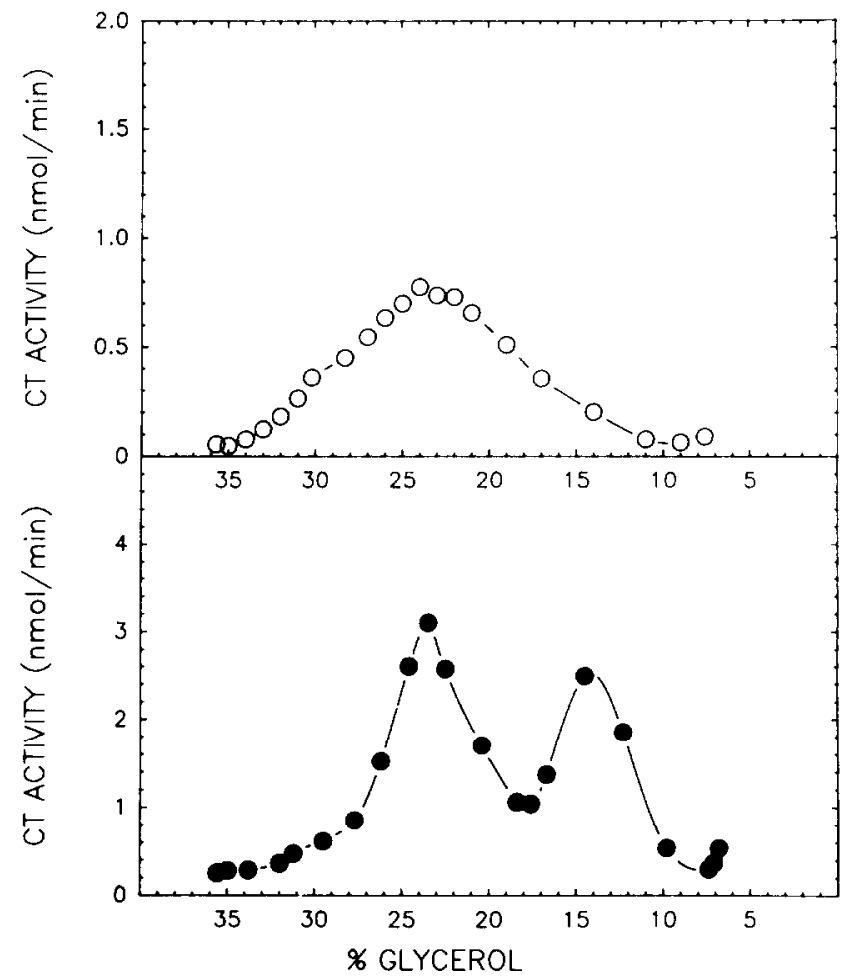

Fig. 6. Glycerol gradient fractionation of Triton X 100 extract from translocated microsomes. Microsomes were isolated by glycerol density centrifugation from postmitochondrial supernatant that was incubated for $15 \mathrm{~min}$ at $37^{\circ} \mathrm{C}$ prior to the gradient isolation. The microsomes were extracted with $0.1 \%$ Triton $X 100$ overnight at $4^{\circ} \mathrm{C}$. 0 , 'Triton extract, $\bullet$, lung postmitochondrial supernatant, $\%$ glycerol refers to the glycerol content of the gradient.

ing, it enhanced the binding produced by oleic acid. The reason for this is unknown. However, it may indicate that either the binding is temperature-dependent or that temperature-dependent changes in membrane structure increase the binding capacity.

\section{Discussion}

Qualitatively, the subcellular distribution of cytidylyltransferase is similar in all tissue and cells so far examined, in that the enzyme is located in both the cytosolic and the microsomal fraction [1]. However, there are, significant differences in the relative amounts of activity in these two fractions. For example, liver microsomes contain only about $7-10 \%$ of the total cytidylyltransferase activity. Lung microsomes, on the other hand, contain $30-40 \%$ of the total activity, when the microsomes are isolated by the usual differential centrifugation method. The lung also differs significantly from liver in the cytosolic content of cytidylyltransferase. Cytidylyltransferase exists predominantly as a high-molecular-weight species (H-form) in adult lung. In liver, the enzyme exists solely as the L-form, with no detectable H-form. Previously, we reported that the $\mathrm{H}$-form in lung was partially active in the absence of 

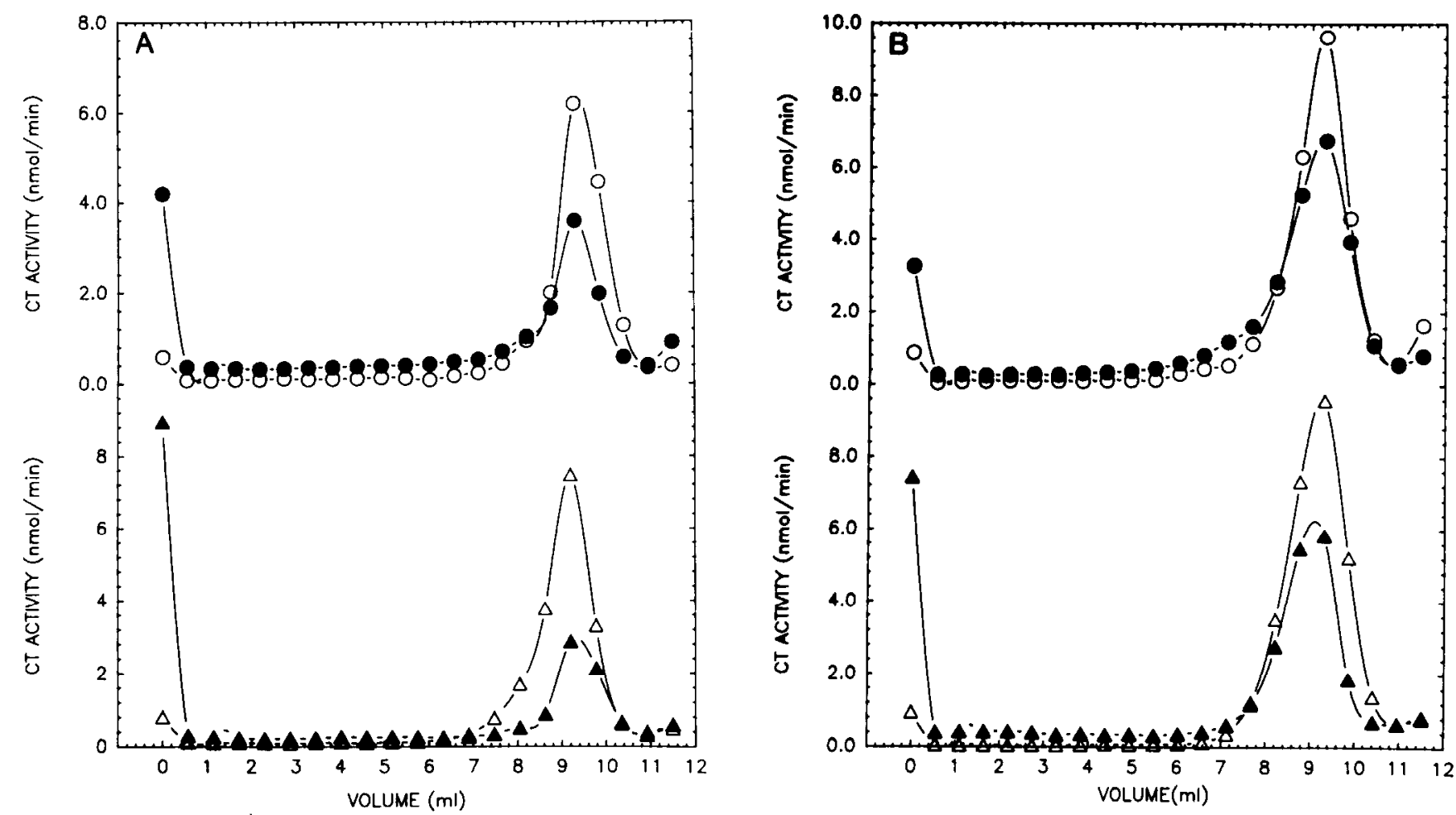

Fig. 7. The effect of incubation at $37^{\circ} \mathrm{C}$ and oleic acid on the distribution of cytidylyltransferase in liver and fetal lung $20000 \times \mathrm{g}$ for $20 \mathrm{~min}$ supernatant (PMS). (A) Adult rat liver, (B) Fetal rat lung (20-d gestation). $\bigcirc$, PMS at $4^{\circ} \mathrm{C}$; $\bullet$, PMS plus $250 \mu \mathrm{M}$ oleic acid at $4^{\circ} \mathrm{C} ; \Delta$, PMS incubated for $15 \mathrm{~min}$ at $37^{\circ} \mathrm{C} ; 4$, incubated at $37^{\circ} \mathrm{C}$ for 15 min then oleic acid added to give $250 \mu \mathrm{M}$.

lipids. Furthermore, the $\mathrm{H}$-form can be dissociated into the L-form in vitro and can be reformed by the addition of lipids which activate the enzyme. We concluded that the active form of cytidylyltransferase is a lipoprotein complex (H-form) composed of the apoprotein (L-form) complexed to lipid [25].

In the present study we have extended this work to include information about the microsomal form of cytidylyltransferase and to examine the relationship between the microsomal form and the cytosolic forms. We conclude that the cytidylyltransferase associated with microsomal membranes exists in a form similar, if not identical, to the H-form in cytosol. This conclusion is supported by the following observations: (1) centrifugation of microsomes through a glycerol density gradient removed over half of the membrane-associated activity. The activity removed was recovered as $\mathrm{H}$-form, (2) Triton X 100, at concentrations below that which can disrupt the membrane, released cytidylyltransferase in a form similar to H-form; (3) chloropromazine dissociated both $\mathrm{H}$-form [25] and microsomal form to L-form, suggesting that the protein lipid interaction of the two forms are similar.

Where is the H-form made? There are two possibilities. One is that the $\mathrm{H}$-form is formed in cytoplasm by the interaction of L-form with lipid to form the active lipoprotein species. The active lipoprotein then binds to membranes. The other possibility is that $\mathrm{H}$-form is produced on the membrane surface as a result of the binding of L-form to membrane. In this case, the cytosolic $\mathrm{H}$-form is produced by dissociation of $\mathrm{H}$-form from the membrane surface. Our results support the latter possibility, i.e., that $\mathrm{H}$-form is produced by the interaction of L-form with membrane. The evidence supporting this conclusion is derived from the in vitro translocation experiments. In these experiments, the binding of cytosolic cytidylyltransferase to microsomal membrane was increased by incubation at $37^{\circ} \mathrm{C}$. The glycerol gradient fractionation indicated that the $\mathrm{H}$-form disappeared when postmitochondrial supernatants were incubated at $37^{\circ} \mathrm{C}$. The activity was recovered in the microsomal fraction and as L-form. The addition of albumin after incubation' interrupted the binding process resulting in the recovery of cytidylyltransferase activity in the L-form. No detectable H-form was present and there was no increase in microsomal activity. These results indicate that $\mathrm{H}$-form was dissociated to L-form when postmitochondrial supernatants were incubated at $37^{\circ} \mathrm{C}$. This is consistent with previous results which showed that $\mathrm{H}$-form was dissociated to L-form when cytosolic preparations were incubated at $37^{\circ} \mathrm{C}$ [25]. The results from the experiments with adult liver and fetal lung demonstrated directly that membranes bind the L-form. In these tissues H-form is not present in the cytosol. Furthermore, the addition of oleic acid to adult liver and fetal lung preparation, 
which contained relatively large amounts of L-form, caused large increases in membrane cytidylyltransferase activity, without the need for incubation at $37^{\circ} \mathrm{C}$. On the other hand, the addition of oleic acid to adult lung preparation, which contained small amounts of L-form, caused only a small increase in membrane enzyme activity at $4^{\circ} \mathrm{C}$. Overall, the results indicate that membranes bind the L-form of cytidylyltransferase and do not bind the $\mathbf{H}$-form. The $\mathbf{H}$-form is readily converted to the L-form. The observations that Triton X 100 extracted $\mathrm{H}$-form from membranes containing translocated enzyme provided direct evidence that $\mathrm{H}$-form was made after cytosolic enzyme bound to the membrane.

Fatty acids have been reported to induce the translocation of cytidylyltransferase in cell culture experiments [2] and in lung subcellular preparations [13]. The results in this paper are consistent with the involvement of fatty acids in the induction of the redistribution of cytidylyltransferase. The binding of cytidylyltransferase in liver and fetal lung preparations was completely dependent upon the addition of oleic acid. However, in adult lung, the largest increase in membrane activity was produced by incubation at $37^{\circ} \mathrm{C}$ without the addition of olcic acid. The fact that this binding could be prevented by the addition of albumin suggested that the binding was promoted by fatty acids. Since the major effect of incubation was to dissociate the $\mathrm{H}$-form to L-form, it is possible that the dissociation also released fatty acids or other lipid promoters which then induced the binding of the newly formed L-form to membranes. The finding that incubation of adult liver and fetal lung preparations did not induce binding supports this idea, because these tissues do not contain $\mathrm{H}$-form in the cytosol.

In conclusion, we propose a model which describes the relationship between membrane-bound cytidylyltransferase and the cytosolic forms in the lung. In this model, L-form binds to a specific domain on the membrane surface where it acquires the necessary lipid components to form the active lipoprotein enzyme ( $\mathrm{H}$-form). The $\mathrm{H}$-form can then, under the appropriate conditions, dissociate into the cytoplasm where it remains as a partially active species, perhaps in equilibrium with L-form. The extent of binding of $\mathrm{L}$-form to membranes would depend on both the concentration of fatty acid or other binding promoters and on the dissociation of $\mathrm{H}$-form to $\mathrm{L}$-form. Thus, in this context, the $\mathrm{H}$-form may serve as both an active species in cytoplasm and as a regulated source of L-form. Regulatory events could alter the dissociation of $\mathrm{H}$-form to $\mathrm{L}$-form and/or promote the binding of $\mathrm{L}$-form to membranes. The fact that $\mathrm{H}$-form is not detectable in some tissues, for example liver, implies that it may have a special functional significance in some tissues. Perhaps, in lung it is involved in some way with the coordination between the synthesis of phosphatidylylcholine for membrane turnover and for the formation of pulmonary surfactant. In this regard, it is interesting that $\mathrm{H}$-form is not present in fetal lung but appears after birth when the need to produce large amounts of pulmonary surfactant becomes important [32].

\section{Acknowledgements}

This work was supported by the Veterans Administration and by NIH Grant No. HP 21992 and No. HD 02871.

\section{References}

1 Tijburg, L.B.M., Geelen, M.J.H. and Van Golde, L.M.G. (1989) Biochim. Biophys. Acta 1004, 1-19.

2 Pelech, S.L. and Vance, D.E. (1984) Biochim. Biophys. Acta 779, 217-251.

3 Rooney, S.A. (1985) Am. Rev. Respir. Dis. 131, 439-460.

4 Feldman, D.A., Dietrich, J.W. and Weinhold, P.A. (1980) Biochim. Biophys. Acta 620, 603-611.

5 Choy, P.C and Vance, D.F. (1978) J. Biol. Chem. 253, 5163-5167.

6 Cornell, R. and Vance, D.E. (1987) Biochim. Biophys. Acta 919. 37-48.

7 Chu, A.J. and Rooney, S.A. (1985) Biochim. Biophys. Acta 834. 346-356.

8 Pelech, S.L., Pritchard, P.H. and Vance, D.E. (1981) J. Biol. Chem. 256, 8283-8286.

9 Pelech, S.L. and Vance, D.E. (1982) J. Biol. Chem. 257, 14198 14202.

10 Radika, K. and Possmayer, F. (1985) Biochem. J. 232, 833-840.

11 Sanghera, J.S. and Vance, D.E. (1989) J. Biol. Chem. 264, 12151223.

12 Sleight, R. and Kent, C. (1980) J. Biol. Chem. 255, 10644-10650.

13 Weinhold, P.A., Rounsifer, M.E., Williams, S.E., Brubaker, P.G. and Feldman, D.A. (1984) J. Biol. Chem. 259, 10315-10321.

14 Pelech, S.L., Cook, H.W., Paddon, H.B. and Vance, D.E. (1984) Biochim. Biophys. Acta 795, 433-440.

15 Wright, P.S., Morand, J.N. and Kent, C. (1985) J. Biol. Chem. 260, $7919-7926$

16 Whitlon, D.S., Anderson, J.E. and Mueller, G.C. (1985) Biochim. Biophys. Acta 835, 369-377.

17 Terce, F., Record, M., Ribbes, G., Chap, H. and Douste-Blazy, L. (1988) J. Biol. Chem. 263, 3142-3149.

18 Kolesnick, R.N. (1987) J. Biol. Chem. 262, 14525-14530.

19 Chander, A. and Fisher, A.B. (1988) Biochim. Biophys. Acta 958, 343-351.

20 Burkhardt, R., Von Wichert, P., Batenburg, J.J. and Van Golde, L.M.G. (1988) Biochem. J. 254, 495-500.

21 Pelech, S.L., Pritchard, P.H. and Vance, D.E. (1982) Biochim. Biophys. Acta 713, 260-269.

22 Wright, P.S. and Kent, C. (1986) Arch. Biochem. Biophys. 245, 104-113.

23 Rooney, S.A., Dynia, D.W. Sinart, D.A., Chu, A.J., Ingleson, L.D., Wilson, C.M. and Gross, I. (1986) Biochim. Biophys. Acta 888, 208-216.

24 Stern, W., Kovac, D. and Weinhold, P.A. (1976) Biochim. Biophys. Acta 441, 280-293.

25 Weinhold, P.A., Rounsifer, M.E., Charles, L. and Felduan, D.A. (1989) Biochim. Biophys. Acta 1006, 299-310.

26 Miller, J.C. and Weinhold, P.A. (1981) J. Biol. Chem. 256, $12662-$ 12665.

27 Laemmli, U.K. (1970) Nature 227, 680-685. 
28 Feldman, D.A. and Weinhold, P.A. (1987) J. Biol. Chem. 262, 9075-9081.

29 Smith, P.K., Krohn, R.I., Hermanson, G.T., Mailia, A.K., Gartner, F.H., Provenzano, M.D., Fujimoto, E.K., Goeke, N.M., Olson, B.J. and Klenk, D.C. (1985) Anal. Biochem. 150, 76-85.

30 Pattnaik, N.M., Ke'zdy, F.J. and Scanu, A.M. (1976) J. Biol. Chem. 251, 1984-1990.
31 Kupferberg, J.P., Yokoyama, S. and Ke'zdy, F.J. (1981) J. Biol. Chem. 256, 6274-6281.

32 Weinhold, P.A., Feldman, D.A., Quade, M.M., Miller, J.C. and Brooks, R.L. (1981) Biochim. Biophys. Acta 665, 134-144. 